\title{
Rede social: saberes e práticas no cotidiano do ex-hanseniano
}

\author{
Social network: knowledge and practices in daily life of ex-leprosy
}

Importante problema de saúde pública, a hanseníase é parte ainda de um indesejado patrimônio da humanidade, associado ao subdesenvolvimento, à exclusão e à dor. Com o fim do internamento compulsório, os leprosários se tornaram grandes comunidades que albergam tanto os ex-hansenianos, como também seus familiares. Diante da lacuna histórica em torno deste fenômeno, desenvolveu-se este estudo objetivando: registrar a história de saúdedoença do ex-hanseniano, com ênfase nos saberes, nas experiências vividas e na práxis dos atores sociais envolvidos desde os momentos iniciais da colonização até os dias de hoje; conhecer o discurso acerca do mundo de vida do Ser (ex) hanseniano na atual conjuntura do Centro de Convivência Antônio Diogo; identificar o que permite ao familiar/agregado não hanseniano se sentir "daqui" e "em casa" nos espaços destinados aos ex-hansenianos. Caracteriza-se como um estudo exploratóriodescritivo, realizado durante o ano de 2008, nas dependências da Colônia Antônio Diogo, no Estado do Ceará, Brasil. Foram tomados, como fonte de informação, documentos pessoais e do acervo da própria colônia, assim como 18 (dezoito) moradores da colônia, entre ex-hansenianos e familiares, aos quais foram aplicados entrevista e o roteiro da História Oral. Os dados foram organizados com o apoio da técnica do Discurso do sujeito Coletivo. Os resultados revelam que a institucionalização da hanseníase acarretou graves perdas, sobretudo, social. A cura faz parte de um capítulo fundamental na vida dos depoentes. Há os que a percebem como uma conquista, outros para os quais a mudança do status da doença não parece mudar muita coisa. Os que ficaram com sequelas acham impossível usufruir da sensação de cura, preferindo limitar-se aos espaços da colônia, evitando, assim, o preconceito; e criticam a condição atual da comunidade, onde existem mais sadios morando do que pessoas doentes. $\mathrm{O}$ apego ao passado e ao lugar onde morou grande parte da vida, a rede de relações, enfim, que o ex-hanseniano insiste em manter, servem, nestas circunstâncias, ao propósito de permitir a identificação com um grupo, favorecendo um vigoroso sentimento de pertença. Nas representações partilhadas por ex-hanseniano e seus familiares acerca do contexto atual do Centro de Convivência Antônio Diogo, ser pessoa curada tem significado simbólico de religação com o mundo "de fora" da colônia, e, junto com isso, de autorreconstrução e aceitação de si.

Ana Carolina Rocha
Dissertação de Mestrado (2008)
Mestrado em Saúde Coletiva,
Universidade de Fortaleza
anacarolinarochapeixoto@yahoo.com.br

Palavras-chave: Hanseníase. História oral. Discurso do Sujeito Coletivo.

Keywords: Leprosy; Verbal history. Speech of the Collective Citizen.

Palabras clave: Lepra. Historia oral. Discurso del Sujeto Colectivo. 